\title{
Fiction in Covid-19 time: a break in production that left room for streaming. \\ DOI: https://doi.org/10.7764/obitel.21.S.2
}

\author{
Authors: \\ Pablo Julio Pohlhammer \\ (https://orcid.org/0000-0003-1387-4463), \\ Francisco J. Fernández Medina ${ }^{1}$ \\ (https://orcid.org/0000-0001-6146-0375)
}

For the first time since this yearbook began, all Obitel member countries were affected by the same phenomenon: the COVID-19 pandemic. The disease caused by the virus SARS COV-2, detected in China by the end of 2019, attained characteristics of a pandemic in less than three months. From March 2020, a confinement period started in world's major cities, affecting not just economic activity but also everyday life of the people, who had to remain home for weeks and even months. Work, education, videoconferences, shopping and even medical consultations moved to internet. Audiovisual fiction became a memory of the normality lost, as well as an escape from the reality featured on the news and from the global campaigns promoting the use of face masks, physical distance, limited capacity and vaccination programs. 2020 turned into a peculiar year since fiction production in Obitel member countries was minimized, but this was not yet the case for consumption. And as soon 
as the confinement was loosened, production had to adapt itself to pandemic protocols and also to address emerging issues related to the new life context. The analysis of 2020 data presented in this report shows the consolidation of a change process in television, emphasizing the relevance of streaming as a distribution technology of exclusive products as well as contents produced by open television. These changes were maybe accelerated by the pandemic but they may become permanent.

\section{Obitel countries and Open TV in $\mathbf{2 0 2 0}$}

The open television landscape in Ibero-American countries shows a great diversity of situations due to: (a) the different importance and role of public television; (b) the level of implementation of digital terrestrial television; and (c) the relevance of each country regional signal. Table 1 shows a reduced but representative version of that diversity. Only national wide networks and their main signals, in those cases where digital terrestrial television has been fully implemented, can be appreciated.

Table 1. National open television networks in Obitel member countries in 2020.

\begin{tabular}{|l|c|c|c|}
\hline \multicolumn{1}{|c|}{ Country } & $\begin{array}{c}\text { Private } \\
\text { TV }\end{array}$ & $\begin{array}{c}\text { Public } \\
\text { TV }\end{array}$ & $\begin{array}{c}\text { Public TV audience } \\
\text { share among main } \\
\text { national signals (\%) }\end{array}$ \\
\hline Argentina & 5 & 1 & 3,2 \\
\hline Brazil & 5 & 2 & 0,9 \\
\hline Chile & 6 & 1 & 18,9 \\
\hline Colombia & 3 & 2 & 10,2 \\
\hline Spain & 4 & 2 & 23,9 \\
\hline Hispanic US & 5 & 0 & 0,0 \\
\hline Mexico & 9 & 4 & - \\
\hline Peru & 5 & 1 & 5,3 \\
\hline Portugal & 2 & 5 & 27,4 \\
\hline Uruguay & 3 & 2 & - \\
\hline Venezuela & 9 & 13 & - \\
\hline
\end{tabular}


The relevance of what is not shown in table 1 varies from one country to another. In addition to what has already been indicated, open television coexists in all the countries with pay television and streaming. But there are two cases related to what has not been mentioned that deserve a special reference. The first one is the Hispanic US where the bulk of television offer corresponds to the Anglophone, which obviously is also available to Hispanic audiences. The other relevant case is Spain where, besides secondary signals, autonomous regional television channels play an important role in their region and, in some cases, have a significant capacity to produce high standard fiction. These channels are not included in table 1, but their productions are indeed contained in tables showing Spanish fiction production and exhibition.

As it can be observed in table 1, the underlying rule shows that private television is the dominant open signal and public TV is secondary, but there are some exceptions. The most notorious case is Spain where $L a 1$ is the third most-watched signal in a very competitive market. The case of Portugal is different since the market is less divided, and channels RTP 1 and RTP2 together represent less than the second of the two private players. The third remarkable case is TVN from Chile that, still competing with a greater number of players, achieved a higher turnout. Considering its contents and its funding, it is not exaggerated to say that this public channel acts like a private one, but its owner is the Chilean State. Finally, it was striking to see the large numbers of public channels available in Venezuela, despite their social insignificance. In 2020, Venezuela was unable to conduct the audience measurement, because the only rating company left the country and it was not replaced by any other. However, figures show that in 2019 the three first private channels concentrated $80 \%$ of the audience, and the other $20 \%$ was distributed among 19 public and private channels. 
Table 2. Fiction's share in TV programming as a percentage of screen time.

\begin{tabular}{|l|c|c|c|c|c|}
\hline & 2016 & 2017 & 2018 & 2019 & 2020 \\
\hline Argentina & 18,4 & 16,3 & 14,2 & 7,2 & 24,3 \\
\hline Brazil & 14 & 13,9 & 13,6 & 11,8 & 12,9 \\
\hline Chile & 34,3 & 29,7 & 25,4 & 27 & 24,2 \\
\hline Colombia & 26,7 & 20,5 & 21,4 & 33,9 & 32,8 \\
\hline Spain & 41,4 & 41,3 & 41,5 & 42,7 & 42,3 \\
\hline Hispanic US & 48,9 & 44,8 & 44,1 & 40,7 & 42,2 \\
\hline Mexico & 14,8 & 15,2 & 16,2 & 15,9 & 12 \\
\hline Peru & 37,3 & 37,9 & 36,5 & 32,8 & 31,3 \\
\hline Portugal & 23,6 & 24,7 & 24,4 & 19,9 & 20,8 \\
\hline Uruguay & 25,9 & 26,4 & 26,8 & 25,7 & 20,4 \\
\hline Venezuela & - & 15,6 & - & 22,1 & - \\
\hline
\end{tabular}

Source: Obitel

Table 2 shows the evolution of fiction's share in total open television programming during the last five years. It represents the entire fiction and not just the Ibero-American one, as it will be seen in sections below. Despite cross-country variations, it can be said that Ibero-American fiction is the dominant on open television in these countries.

Excepting Argentina and Venezuela, which have local situation that go beyond television matters, abrupt changes in figures demonstrating fiction participation in TV programming have not been observed. Unlike pay television and streaming, an alignment between TV time and type of contents to be consumed in certain time has been verified on open television. Fiction consumption, as well as other television genres, tends to be routine and to be coupled to activities of daily living favoring a certain inertia in channels' programming strategies.

However, inertia does not mean the absence of changes but their slowness. Chart 1 contains the data from previous table. By adjusting a linear trend in data from each country (except Venezuela), it can be observed that in seven out of ten countries fiction participation has decreased, while in Spain it has remained the same, and some 
abrupt changes have occurred in Argentina and Colombia, but they are more related to some kind of structural adjustment that to evolution.

\section{Chart 1. Fiction time's share in open television}

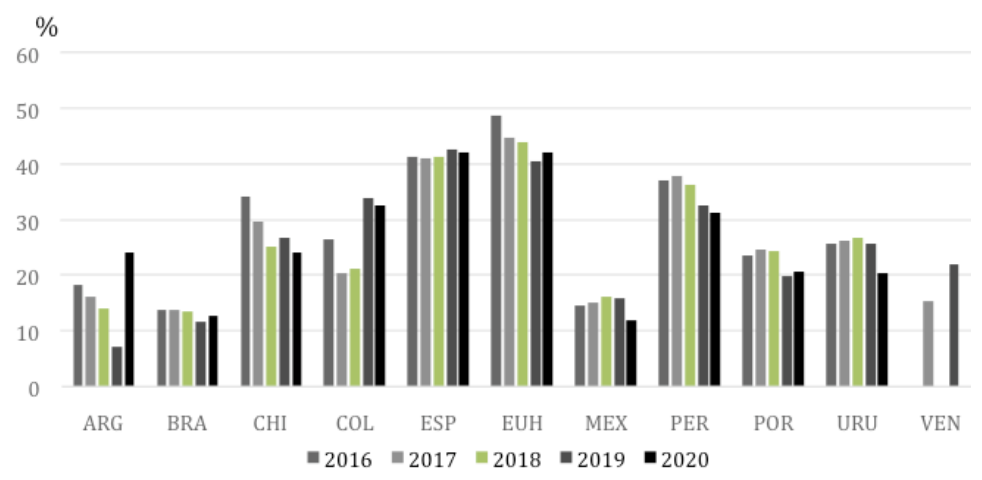

Source: Obitel

Chart 1 also demonstrates a second relevant fact. While in Spain and the US Hispanic fiction's share reached $42 \%$ of programing time, in Brazil and Mexico just reached 13\% and 12\%, respectively. This represents less than a half of the average share obtained in the rest of Obitel countries. Excepting Brazil and Mexico, average fiction' share is around $30 \%$ of programming time. It is paradoxical that, according to table 3, these two countries along with Spain exhibited a larger volume of TV fiction premiere during the two years before the anomalous 2020 .

The health crisis resulting from the COVID-19 pandemic changed people's daily life from all the Obitel member countries. As the Uruguay report indicates, the need to be informed about the disease progression and the actions of the authorities to control it made TV audiences, in different moments of 2020, to be more attentive to news and life press conferences from their respective governments, increas- 
ing rating during those periods. Peru also reports the same phenomenon, but also mentions a sevenfold increase of education TV programs. Argentina experience tells, according to some consultancies, that the demand of more cheerful TV contents for the infantile-juvenile audience, who spent more time at home due to the pandemic, increased. Colombia reports a decrease in the production of fiction, and the lack of new titles was compensated by series and telenovelas taken from the truck of memories.

\section{Television fiction in Obitel countries in $\mathbf{2 0 2 0}$.}

The second section of each country chapter informs about Ibero-American TV fiction premiere broadcast in each of them. TV fiction premiere, in addition to presenting fiction locally produced and broadcast, represents an indirect measure of each country productive capacity, and when it refers to other countries fiction, gives an idea of fiction trade flows.

Table 3 has been made based on tables 2 from each 2020 national chapter and on the four previous yearbooks, and it considers exclusively national fiction broadcast and co-productions in which each country has participated.

Table 3. Offer of hours of national fiction premiere on open television (2016-2020) ${ }^{2}$.

\begin{tabular}{|c|c|c|c|c|c|c|c|c|c|c|c|}
\hline Year & ARG & BRA & CHI & COL & ESP & EUH & MEX & PER & POR & URU & VEN \\
\hline 2016 & 584 & 1435 & 1080 & 1121 & 1806 & 1059 & 706 & 666 & 1232 & 9 & 576 \\
\hline 2017 & 756 & 1431 & 931 & 1048 & 1977 & 1000 & 1545 & 553 & 1293 & 11 & 522 \\
\hline 2018 & 526 & 1299 & 722 & 520 & 1742 & 1171 & 2070 & 621 & 755 & 16 & - \\
\hline 2019 & 376 & 1307 & 747 & 733 & 1451 & 1071 & 1330 & 560 & 1025 & 3 & 35 \\
\hline 2020 & 62 & 416 & 274 & 271 & 1217 & 661 & 906 & 442 & 795 & 47 & 3 \\
\hline
\end{tabular}

Source: Obitel

2 Fort the US, only Hispanic population is considered for this study. 
Comparison with data from the four previous years evidences the drastic production plunge in 2020 as a consequence of confinements and other restrictions due to COVID-19. Total Obitel fiction premiere dropped by $41 \%$ in contrast with 2019 , and in some cases the production decline reached $80 \%$ and $90 \%$. In absolute terms, the largest drop occurred in Brazil, which $68 \%$ of decline represented 891 hours less of fiction. The only exception was Uruguay that had an explosive increase, but from a very low baseline.

2020 anomaly should not hide a more structural issue. As it can be observed, total Obitel production decline of $41 \%$ need to be aggregated to the accumulated fall of $22 \%$ experimented during the two years before the pandemic. This setback in TV fiction production for open television should not mean a decline in productive capacity. The volume of production premiere on VOD, shown further down, suggests that, at least, one percentage of the phenomenon corresponds to a displacement from one window display to another.

Another interpretation of table 3 gives a picture of the competition level among member countries. A common feature in Obitel countries is their capacity as purchasers and, with varying degrees of success, as sellers in the same Ibero-American market. If all these countries follow a same pattern of production and local exhibition as a pre-sale phase, therefore table 3 can be considered as a measure of future volume of original production that will be offered in TV fiction market. A significant fact is that, excepting Mexico/Colombia and Mexico/Portugal, correlations between pair of countries are positive. A common possible interpretation is that local production is not motivated by exports, but by local conditions in each country, and these can usually be affected by common economic factors. There are two exceptions to this rule because the US is a significant market for Mexican and Colombian productions, and so is Brazil to Mexico and Portugal. 
Chart 2 considers the two last years of table 3 in order to highlight the drop of local fiction premiere exhibition, and it cross-checks it with population from each country.

\section{Chart 2. Fiction productive capacity on open television}

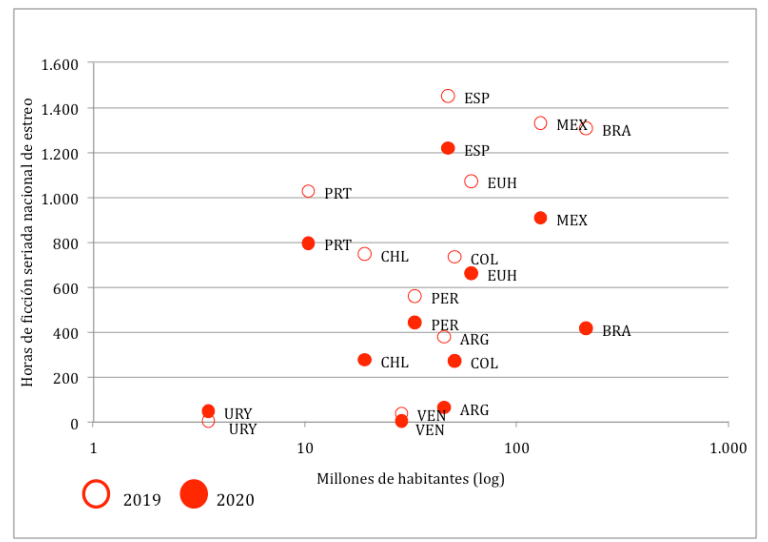

Source: Obitel, World Bank, US Census Bureau ${ }^{3}$

Taking 2019 as the reference year, the Obitel country showing the highest production of TV fiction hours per capital was, with obvious supremacy, Portugal with 99 hours per million people, followed by Chile and Spain with 39 and 31 hours, respectively. This simple indicator helps to compare levels of production between small countries, such as Uruguay with 3,5 million people, and big countries such as Brazil with 213 million people.

However, the size of population is not enough to explain the different volumes of production. A better approach can be obtained by using a simple model with an adequate adjustment $t^{4}$, consisting in

$3 \mathrm{R}^{2}=0.92 ; \mathrm{R}^{2}{ }_{\text {ajust }}=0.77 ; \mathrm{F} \square \mathrm{F}_{\mathrm{c} .}$ A more elaborate model should include, at least, variables as advertising investment in television industry and production in other "display windows" and productions from other platforms.

4 Venezuela and the US were not included for not having data equivalent to what it would be the GDP of a specific population group. 
a simple linear regression of population and GDP per capital acting as independent variables. In this case, results suggest that in 2019 Argentina, Brazil and Uruguay presented a production of fiction hours below expectations, while productions from Spain, Colombia and Peru were above the predicted by the model ${ }^{\square}$. It would have no sense to apply the same model to 2020, because the reasons for the general decline of production, as previously mentioned, differ from those from 2019.

Table 4 has also been built based on tables 2 from each national chapter. In this opportunity, the hours of TV fiction premiere from each country were put together in a table to obtain a map of export flows among countries. This is about fiction released in a specific country that could have been previously exhibited in other places.

Mexico, Brazil and Colombia, in this order, are shown as countries with a robust exporting industry. Hispanic US is located far below in this list, and the rest of the countries has small volumes. In an opposite way, Peru is the major importer, not just in volume but also in the variety of countries where the fiction consumed by its population comes from. In terms of diversity but with half of the volume, this country is followed by Uruguay and Chile on the classification.

Table 4. Ibero-American fiction premiere exhibited in each country during 2020.

\begin{tabular}{|c|c|c|c|c|c|c|c|c|c|c|c|c|c|}
\hline & \multicolumn{13}{|c|}{ Exhibition country } \\
\hline \multirow{13}{*}{ 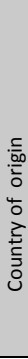 } & Hours & ARG & BRA & $\mathrm{CHI}$ & $\mathrm{COL}$ & ESP & EUH & MEX & PER & POR & URU & VEN & \begin{tabular}{|l|} 
Total \\
\end{tabular} \\
\hline & ARG & - & 0 & 0 & 0 & 0 & 0 & 0 & 119 & 0 & 17 & 69 & 204 \\
\hline & BRA & 179 & - & 350 & 0 & 23 & 76 & 460 & 112 & 253 & 364 & 0 & 1.817 \\
\hline & $\mathrm{CHI}$ & 0 & 0 & - & 0 & 0 & 0 & 0 & 138 & 0 & 37 & 0 & 175 \\
\hline & $\mathrm{COL}$ & 153 & 0 & 31 & - & 32 & 154 & 371 & 287 & 0 & 2 & 449 & 1.479 \\
\hline & SPA & 1 & 0 & 3 & 0 & - & 0 & 10 & 2 & 0 & 17 & 0 & 34 \\
\hline & HUS & 23 & 134 & 8 & 0 & 79 & - & 44 & 272 & 0 & 0 & 1 & 560 \\
\hline & MEX & 0 & 147 & 328 & 117 & 206 & 1.013 & - & 570 & 0 & 55 & 148 & 2.583 \\
\hline & PER & 0 & 0 & 0 & 0 & 0 & 0 & 0 & - & 0 & 0 & 0 & 0 \\
\hline & POR & 0 & 141 & 0 & 0 & 0 & 0 & 0 & 0 & - & 0 & 0 & 141 \\
\hline & URU & 0 & 0 & 0 & 0 & 0 & 0 & 0 & 0 & 0 & - & 0 & 0 \\
\hline & VEN & 0 & 0 & 0 & 0 & 0 & 0 & 0 & 0 & 0 & 0 & - & 0 \\
\hline & Total & 356 & 421 & 720 & 117 & 339 & 1.243 & 885 & 1.500 & 253 & 493 & 666 & 6.993 \\
\hline
\end{tabular}


At the other end, there are countries such as Colombia and Portugal that import all the TV fiction from one country: Mexico in the case of Colombia and Brazil in the case of Portugal.

Chart 3 is the result of combining tables 3 and 4, and it shows the volume of TV fiction premiere exhibited in each country and to what extend local TV fiction coexists with TV fiction from the rest of Ibero-America.

Regarding the major export countries, Brazil and Mexico are also large importers, and their local fiction represent $50 \%$ of what have been exhibited. This is not the case of Colombia that imports just 30\% of the exhibits. From a fiction autarky point of view, Spain and Portugal just import $22 \%$ and $24 \%$, respectively, of what have been exhibited. At the opposite end, Argentina, Uruguay and Venezuela depend in $85 \%, 90 \%$ and $99 \%$, respectively, on fiction imported from other countries.

Chart 3. Ibero-American fiction premiere exhibited during 2020.

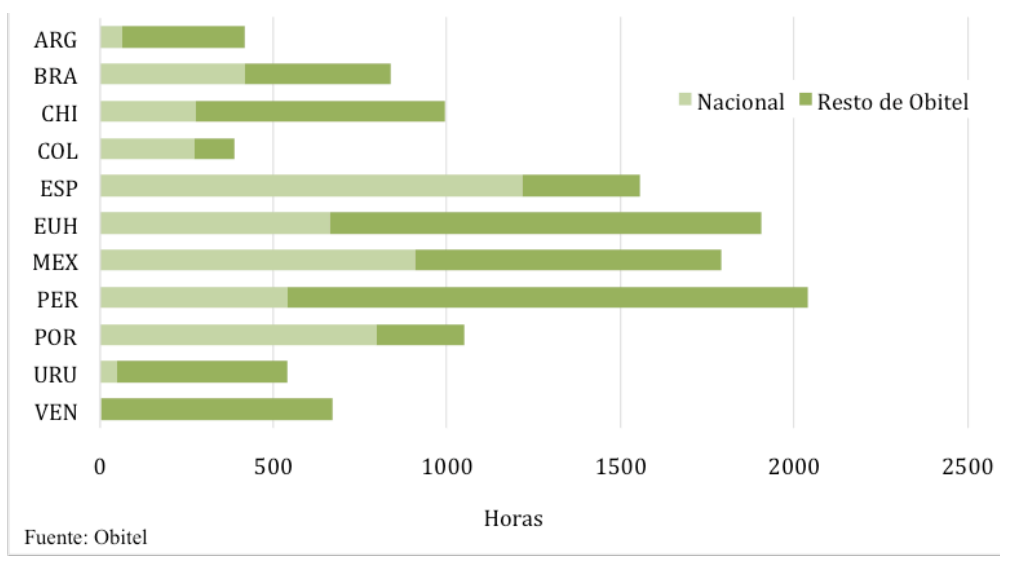


Tables 5 and 6 disaggregate TV fiction premiere exhibited in each country according to their formats. Table 5 does so by showing the quantity of titles in each format, while table 6 shows the percentage distribution of hours exhibited according to each format in every country.

Considering the number of titles, telenovelas and series are the dominant formats with 69 and 64 titles, respectively, out of a total of 162. But when the quantity of hours produced is considered, telenovela presents itself as the hegemonic format in the region, reaching a participation of $76 \%$ of exhibited time.

Table 5. Number of national titles by fiction premiere formats during 2020 .

\begin{tabular}{|l|c|c|c|c|c|c|c|c|c|c|c|c|}
\hline \multicolumn{1}{|c|}{ Format } & ARG & BRA & CHI & COL & SPA & HUS & MEX & PER & POR & URU & VEN & Total \\
\hline Telenovela & 1 & 6 & 5 & 25 & 7 & 7 & 5 & 7 & 6 & 0 & 0 & 69 \\
\hline Series & 0 & 9 & 6 & 12 & 20 & 1 & 5 & 1 & 8 & 1 & 1 & 64 \\
\hline Miniseries & 4 & 1 & 1 & 0 & 4 & 0 & 0 & 2 & 3 & 0 & 0 & 15 \\
\hline Telefilm & 0 & 0 & 0 & 0 & 0 & 0 & 0 & 0 & 1 & 0 & 0 & 1 \\
\hline Unitary & 0 & 2 & 0 & 0 & 0 & 1 & 3 & 0 & 1 & 0 & 0 & 7 \\
\hline Docudrama & 0 & 0 & 0 & 0 & 0 & 0 & 0 & 0 & 0 & 0 & 0 & 0 \\
\hline Others & 0 & 5 & 0 & 0 & 0 & 0 & 0 & 1 & 0 & 0 & 0 & 6 \\
\hline Total & 5 & 23 & 12 & 37 & 31 & 9 & 13 & 11 & 19 & 1 & 1 & 162 \\
\hline
\end{tabular}

Source: Obitel

Table 6. Time by national fiction premiere format exhibited during 2020

\begin{tabular}{|c|c|c|c|c|c|c|c|c|c|c|c|c|}
\hline Format & ARG & BRA & CHI & COL & SPA & HUS & MEX & PER & POR & URU & VEN & Total \\
\hline Telenovela & $57 \%$ & $82 \%$ & $82 \%$ & $75 \%$ & $85 \%$ & $93 \%$ & $47 \%$ & $78 \%$ & $89 \%$ & - & - & $76 \%$ \\
\hline Series & - & $8 \%$ & $16 \%$ & $25 \%$ & $14 \%$ & $3 \%$ & $28 \%$ & $5 \%$ & $9 \%$ & $100 \%$ & $100 \%$ & $19 \%$ \\
\hline Miniseries & $43 \%$ & $2 \%$ & $2 \%$ & - & $1 \%$ & - & - & $2 \%$ & $1 \%$ & - & - & $1 \%$ \\
\hline Telefilm & - & - & - & - & - & - & - & - & $0,2 \%$ & - & - & $0,02 \%$ \\
\hline Unitary & - & $4 \%$ & - & - & - & $4 \%$ & $25 \%$ & - & $0,1 \%$ & - & - & $3 \%$ \\
\hline Docudrama & - & - & - & - & - & - & - & - & - & - & - & - \\
\hline Others & - & $8 \%$ & - & - & - & - & - & $15 \%$ & - & - & - & $1 \%$ \\
\hline
\end{tabular}




\section{VoD Monitoring of 2020}

The steady growth of streaming as a format for VOD content distribution continued despite de COVID-19 pandemic. In fact, the confinement experimented by the word population during half of 2020 produced a significant increase in consumption of this platform on demand, which was also boosted by the introduction of new, national and global, players in the sector. However, restrictions resulting from the pandemic impacted the audiovisual production, even though some titles, concentrated in few countries, were produced for VOD.

Table 7 of this section is developed on the basis of tables 6 from each country chapter. They identify all the national and IberoAmerican titles of TV fiction premiere available in each country in different VOD platforms, but table 7 just considers local titles and coproductions in which the country concerned takes part.

Table 7. Number of serial fiction titles released in each country in different platforms during 2020. Co-productions including the concerned country in brackets.

\begin{tabular}{|c|c|c|c|c|c|c|c|c|c|c|c|c|}
\hline Platform & ARG & BRA & $\mathrm{CHI}$ & $\mathrm{COL}$ & SPA & HUS* & MEX & PER & POR & URU & VEN & Total \\
\hline Netflix & 3 & $7 \quad(2)$ & & 5 & 8 & 3 & 6 & & & & & $32 \quad(2)$ \\
\hline Prime Video & (1) & 5 & $2(2)$ & & $\begin{array}{|ll|}9 & (1) \\
\end{array}$ & & 4 & & & & 1 & $21 \quad(4)$ \\
\hline Globo Play & & $19(3)$ & & & & & & & & & & $19 \quad(3)$ \\
\hline Movistar & 1 & & & & $10(1)$ & & & 2 & & & & $13 \quad(1)$ \\
\hline Atresplayer & & & & & 7 & & & & & & & 7 \\
\hline Claro & & & & & & & 6 & & & & & 6 \\
\hline BoxBrazil Play & & $\begin{array}{|ll|}5 & (1) \\
\end{array}$ & & & & & & & & & & $\begin{array}{ll}5 & (1) \\
\end{array}$ \\
\hline Cablevisión Flow & $\begin{array}{|ll|}5 & (1) \\
\end{array}$ & & & & & & & & & & & $\begin{array}{ll}5 & (1)\end{array}$ \\
\hline $\mathrm{HBO}$ Go & & 1 & & & 3 & & & & (1) & & & $\begin{array}{ll}4 & (1) \\
\end{array}$ \\
\hline Cont.ar & 3 & & & & & & & & & & & 3 \\
\hline OPTO & & & & & & & & & 3 & & & 3 \\
\hline Caracol Play & & & & 2 & & & & & & & & 2 \\
\hline Orange TV & & & & & $\begin{array}{|ll|}2 & (1) \\
\end{array}$ & & & & & & & $\begin{array}{ll}2 & (1) \\
\end{array}$ \\
\hline RTP Play & & & & & & & & & 2 & & & 2 \\
\hline AméricaTV Go & & & & & & & 1 & & & & & 1 \\
\hline Blim & & & & & & & 1 & & & & & 1 \\
\hline Fox España & & & & & 1 & & & & & & & 1 \\
\hline TNE & & & & & 1 & & & & & & & 1 \\
\hline UN3TV & & & & & & & & & & $\begin{array}{|ll|}1 & (1) \\
\end{array}$ & & $\begin{array}{ll}1 & (1) \\
\end{array}$ \\
\hline Total & $12(2)$ & $37(6)$ & $2 \quad(2)$ & 7 & $41 \quad(3)$ & 3 & 18 & 2 & $\begin{array}{|ll|}5 & (1) \\
\end{array}$ & 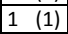 & 1 & $129(15)$ \\
\hline
\end{tabular}


*Hispanic US only includes productions in Spanish made within the US. But, if standard definition of origin is applied to the producer companies, all titles produced by Netflix, Prime Video and other American platforms may be considered US productions or co-productions.

In 2020, Spain and Brazil stand out as the main producers of series for streaming platforms, as they accumulate 41 and 37 titles, respectively, without considering co-productions. They already held these positions in 2019 with 29 and 23 titles each, but in 2020 they kept growing and overcame Mexico, which maintained the same 18 titles obtained in 2019, a figure very similar to 16 titles produced in 2018 .

Spain shows the higher rate of growth, and over the last three years without considering co-productions, increased the number of titles from 16 in 2018 to 41 in 2020. This growth cannot only be explained by the installation of the first Netflix production center in Europe in 2019, since this company only represented the fifth part of Spanish premiere.

Excluding Chile and Hispanic US from the total, in order to use only comparable figures at the aggregate level from the three previous periods and without considering co-productions, the growth of productions for platforms in Obitel market is significant, and it does not seem to have stopped during the pandemic: 69 titles in 2018, 101 in 2019 and 124 in 2020. It will be necessary to wait until 2022 to know if the difficulties experienced during the pandemic in 2020 and 2021will be reflected in number of titles to be release that year.

In section two, a downward trend in the number of hours of TV fiction for open television was noted. Although the number of hours produced for television responds mainly to telenovelas, and the increase of VOD series does not seem to compensate that fall.

Using the information about time and episodes from open television corresponding to 2020 as a reference, which is the only 
data available, it can be said that in the Obitel area telenovela is 3,7 times the number of broadcast hours involved in a series. Nevertheless, variations among countries are high and range from 1,7 times in Mexico, whose series as well as Colombian tend to be longer, to 17,5 times in Spain, which has longer telenovelas and shorter series than the region average.

Table 7 shows 19 streaming platforms that have released fiction contents originated in one or more Obitel countries. Two thirds of titles released correspond to four of those platforms: two American platforms (Netflix and Prime Video), one Brazilian (Globo Play) and one Spanish (Movistar). The rest is represented by platforms of different sizes that have released between seven and four titles.

On the other hand, most of the streaming platforms, 15 out of 19 , produce only in one country. Three out of the four already mentioned (Netflix, Prime Video and Movistar) and HBO Go are exceptions. Despite their big size, companies such as Globo Play or Claro produce in a single market.

To produce fiction in one country means to compete for financing, talents and creative resources. In this sense, a more intense competition is observed in countries showing a higher level of production. In Spain, which produced 41 titles plus three co-productions, production is distributed in eight platforms. Brazil, Mexico and Argentina, countries ranked after Spain in terms of number of titles, have, each one, five platforms. For the rest of the countries the number of streaming platforms producing fiction is lower. 


\section{Fictions analysis: Open TV, VoD and transmedia expressions on social networks}

The COVID-19 pandemic affected the fiction market to the point that a production had to be suspended in Argentina for not being able to continue filming, and the production company had to start a process of downsizing. Brazil experimented a similar situation, and five out of the ten titles that produced the higher interactions in social medias were reruns of telenovelas, such as Avenida Brasil, Fina Estampa and La Fuerza del Querer. Peru experimented, even if the figures are low, an increase of unedited titles and reruns, which totaled 153 during 2020. 11 of them were national inedited productions belonging to the same TV channel. This is not the case of Spain that showed a high diversity of VOD titles, and 79,1\% of this fiction was released in 2020 for the first time. A novelty in this market is the start of the first AVOD (Advertising-Based Video on Demand), a new streaming service without registration and for free.

The impact of confinement on audiovisual consumption can also be observed in VOD. Since people had to stay home and schools had to close, initiatives of remote education found an ally in television for delivering their contents. In Uruguay, A C+ Maratón Transmedia was created, by the conduction of a young lady youtuber and a very known young gamer, to support families and students, especially young people. In Portugal, channel RTP Memoria, dedicated to broadcast classic contents and files, was restructured for broadcasting distance learning with a strong online component.

One of the identified trends in some countries was the use of several platforms to access audiovisual productions, in particular, YouTube and social medias. In Chile, public television created a channel on a platform called Telenovelas y series / TVN; however, it operates 
more like a repository than an instance for interaction and transmedia, and it is not integrated to the channel content strategy. In Peru, the multiplatform approach was assumed as a complement to open television, as it is mentioned in this country report in section about the America TVGO case, the most important VOD platform in Peru.

TV channels and VOD platforms are using their accounts on social networks such as Twitter and Facebook to promote their titles regionally (Latin America) and locally (country). This is the case of Mexico, where Netflix local account in Facebook, @Netflixmx, broke the 73 million followers. In Venezuela, TV channels, like Televen, activated their Instagram accounts to promote their titles by using flyers. But, the user's feedback consisted in giving their opinion about the programming and in highlighting signal reception problems, reinforcing the messages with sad emoji.

In Peru, telenovela Mi Vida sin Ti (2020) raised a number of debates and discussions in social medias, in which actors and actress participated to sensitize people about gender violence that has been far from diminishing during the COVID-19 pandemic. Instagram was also used as a space for interacting with the audience, as it is the case of fiction series Si Solo Si from the Argentine public television, whose actors performed several lives relating to disability. For its part, the Spanish series \#Luimelia took advantages of the use of the hashtag with its name to promote chats and threads in Twitter, in order to get closer to the target audience. This is a spinoff from the series Amar Es Para Siempre, about two characters, Luisita and Amelia, whose mutual love is developing in chapters of no more than 10 minutes. The blending of names to create a title is something also observed in the Brazilian fanfiction Malhação-Viva a Diferença, which is also about a lesbian couple, Lica y Samantha, known on social medias as "Limantha". The same phenomenon can be detected in 100 Días para Enamorarnos (Telemundo, USA), where two support characters, Ale, 
a transgender boy in transition to become Alex, and Lucia have an affair. As it happened to \#Luimelia and Limantha, comments about Lucía and Ale flooded social networks, and even some groups supporting this romance \#Luciale o \#Lucialex were created in Facebook. Moreover, the use of stickers on instant messengers was also observed, especially in Brazil, where contents generated by users (User Generated Content) were largely memes related to reruns of telenovelas. Spanish series $L a$ Valla, addressing a dystopic issue, used a content transmedia strategy, and even developed a microsite including exclusive content, such as a clandestine radio and phone videos from year 2045, when the series is set in. La Valla is a production from Atresmedia, exhibited in its VOD platform, Netflix, and then on the open TV channel, Antena 3.

But fiction was not the only content under the auspices of international VOD platforms and national televisions. Taking advantages of the confinement and the closure of theaters, night clubs and auditoriums, lives were offered under the "exclusive contents" format. In this sense, Portugal created RTP Palco, a VOD offer for shows, theater, music and dance. But YouTube became the most versatile platform, and this service was even used by some independent producer companies that produced web series, for instance the Aisla2 from Colombia. In Mexico, this online space was used to address topics not covered by open television, such as gender diversity and LGBTTTQI+ community. For that purpose, programs like La Más Draga, La Bastarda and Ana, La Chica Bolera were created. The same happened in Brazil where independent productions like Esconderijo, The Stripper, Contos Latentes and Magenta e Ellas, among others, addressed the same thematic. 


\section{Highlights of the year}

Open television programming in most of the Obitel member countries was disrupted by the health emergency. Daily reports about contagious, percentage of samples testing positive for COVID-19 and the untimely passing of hundreds (and in some periods thousands) of people had a guaranteed space on screen.

Added to all this were the talk shows, analysis, scientific divulging programs, political debates, news and magazines addressing diverse aspects of the pandemic at the individual, familiar, social, national and international levels, focusing on different groups of people (kids, students, parents, elderly, technical and medical staff, etc.). This fact was highlighted by the Argentina team presenting how, in the distribution of programming hours, informative content was imposed over entertainment, series and telenovelas. But, regarding the raking, public choice in that country is the opposite, and comedy, entertainment and telenovela stand out. In any case, there is no doubt that Ibero-American TV audiovisual content was sieved through COVID-19, although, as we shall see below, this no fiction relevance could not be reflected in audiovisual fiction, whose production was deceased by health restrictions.

This is how reruns prevailed in TV programming during the first half of 2020. Those productions, made in pre-pandemic times, represented a very different reality from what people were experimented during the harder moments of COVID-19, evidencing a big difference between what has been shown and what has been actually lived. This is maybe why reruns selection, in some cases, prioritized relaxation, humor and the development of simple issues, almost as a scape of reality. Indeed, this fact was reported by Colombia; for instance, Pedro el Escamoso and Pasión de Gavilanes became a space for entertainment and family reunion. 
Home confinement transformed houses and apartments into multi target places for parents to work and for kids virtually attend school, besides all the housework involved in being 24 hour and seven days a week lockdown. In some region countries, tele-education initiatives were proposed, some of them based on official school curricula boosted by education authorities, and others had no curricular programming but offered cross-cutting education objectives. One of the main examples is the initiative from Peru government, Aprendo en Casa, designed for school children to have distance learning, even though broadcasters just offered one or two hours of their programming. $T V$ Educa Chile was a different case, and it is considered a unique experience in which all private open television channels and the public signal agreed to broadcast, in their second digital channel from the assigned multiplex, the same programming and the same educative contents for children. Likewise, the signal was also broadcast by the main cable operators, satellites, IPTV and channels 'sites. The main provider of this type of contents was the National Council for Chilean Television (CNTV), but other channels, with some files related to this subject, also participated. CNTV included a particular slot for official curricular content generated by the Chilean Ministry of Education.

In this context where audiovisual content consumption in confinement seems to respond to classic TV targets, such as inform, entertain and educate, the Portuguese team choose the development of a streaming strategy by open television channels as the element to be highlighted from 2020. Beyond affecting television, new platforms boost production, allow audiences to focus on content and give access to a variety of programs. As the Chilean public channel, TVN, that created an online channel to broadcast their own telenovelas; Portuguese public channel, RTP, uses its platform RTP Play like a repository and file, even though it is not the only streaming experience in Portugal. Spain demonstrated that it could have a large number of content pre- 
mieres, domestically produced and distributed as part of different VOD offers available. There were 44 fiction premieres on these platforms, and some of them cover virtually all genres.

As well as Chile started 2020 with the continuation of social unrest and massive protests in main country cities initiated in October of the previous year, the United States also had social intense moments. Apart from the high number of contagious that this country had during the pandemic, along with Brazil and India, the electoral contest between the former president Donald Trump and his contender Joe Biden, from the Democratic Party, extreme population's positions to existential levels. The murder of George Floyd by the police gave an impetus to the Black Lives Matter movement, with demonstrations all over the country. This is how TV networks, Univision and Telemundo included, had a special coverage of the presidential election in this context of social protests, in addition to the COVID-19 news which had already started to be part of TV programming.

Other regrettable reality from 2020 was the gender violence that gave diverse women's collective movement impetus to stop aggression against women, girls and adolescent. Both, Peru and Mexico reported details of this reality. In fact, the Mexican team informs about an increment of $39 \%$ in attention and support requests to the Refuges National Network (that protects women suffering from domestic violence). This reality was reflected in the telenovela Vencer al Desamor, which is about a journalist researcher conducting a professional inquire about a serial femicide, and in every chapter the audience is recommended to denounce any violent situation. At the regional level, this impact is added to those highlighted by the Peruvian report in a discouraging context of gender violence that bleeds the country. Telenovela from Del Barrio Producciones Mi Vida Sin Ti has a central axis on the different forms of gender violence against women, and its impact moved to social networks, generating discussions with active partici- 
pation of actress and actors in live, aimed at breaking down models and paradigms standardized in Peruvian society that form part of the violence against women.

\section{Topic of the year: Ibero-American television fiction in times of pandemic}

As it has been seen, COVID-19 affected all Obitel countries in deferent ways and proportions. When the pandemic was declared by the WHO, countries from the northern hemisphere were in the middle of their production year, while in southern Latin America countries activities were just getting started, and some of these countries were just returning from summer vacation. This explains the diversity of strategies implemented by the TV channels and the fiction audiovisual industry when facing an uncertain 2020. In any case, to opt for productions already completed and reprises was the best choice to have a whole TV programing. All the TV channels had to adjust their 2020 premiere calendar, deferring or cancelling projects. In consequence, given the decrease of canned production, live TV strip products were also used. Anyhow, the severe restriction derived from the pandemic and the confinement during first half of 2020, such as the limited capacity and the virus traceability through continuous COVID-19 tests became real barriers to fiction audiovisual production, considering the necessity of actors, production managers and support and technical staff.

If we have to summarize Ibero-American fiction content production in one word, it would be crisis. There is no doubt that one of the most affected sectors by the pandemic was the audiovisual. The US report facilitates data that help to understand the dimension of the impact: in March 2020, Netflix, Amazon, Disney, Warner Bros, Apple TV, NBC, CBS, Fox and ABC production was completely stopped, and 
the production of around $97 \mathrm{TV}$ series and 21 pilots was suspended as well. As it has been already mentioned, this is an activity that requires, in all its phases, the presence of a significant group of people in the same place. This is the reason why health restrictions affected one of minimum conditions needed for professional practice in the sector, and many crises situations were triggered in the industry all around the world, except for those productions whose filming phase was already completed. Because, even if some stages of the production chain do not require being present, like script creative writing or audiovisual montage and postproduction, it is true that the main input, the work of actors and production staff, was subject to maximum limitations. In fact, health restrictions limiting distance among people to, at least, one meter, "at the best", made impossible to actors to perform scenes that implied physical closeness, and certainly not scenes with some intimacy or physical contact. Therefore, those activities that could be performed along, respecting social distance and with no necessity of being in the same place, were the only to be undertaken during the first half of 2020, and even during the worst moment of the second and third waves of the pandemic. Most of them corresponded to fiction production that took advantages of the moment to create different ad-hoc stories, for instance, about psychotherapist seeing patients remotely (Chile) or teenagers confined with their parents (Uruguay).

As above mentioned, streaming turned out to be a real distribution channel for fiction audiovisual, offering different options of contents and display devises for visualization (from cellphones to Smart TV). Venezuela reports a diversity of titles on YouTube and Instagram TV platforms. This is the case of Amor sin Tapabocas, a miniseries that uses humor to perform a social criticism, while Readaptados is a web show made from chats and video calls about the experiences involved in the confinement. On its part, Brazil took advantage of the so called video calls pandemic resource to incorporate it into the stories, and 
thus adjust itself to health restrictions. Diario de Um Confinado is an example of this: a comedy about a man who lives along in an apartment where new characters appear but through internet calls.

These initiatives appeared as options along with reruns of fictions that have succeeded in previous years, among which stand out Turkey telenovelas that were shown in prime-time, as it is indicated in the US report. When fiction reruns had a national origin, actors, as occurred in Argentina, who took part in them exercised their performance rights, driving by the difficult economic situation originated by the stop of a significant proportion of the audiovisual industry.

This crisis also affected structural aspects of the industry. Many audiovisual producer companies were on the verge of bankruptcy or were out of business. Dismiss employees and downsize were the first attempts to avoid lockout, as it happened to once successful PolKa. In Mexico, Televisa publicly informed about its economic losses for more than half the year, and despite the lifting of certain health restrictions for production, it closed the year with uncertainty about the impact of the pandemic on advertisement income. In any event, profits reductions were compensated by lower spending in fiction audiovisual production caused by the stop of the activity for nearly three months.

According to a well-known saying, in the midst of every crisis, lies great opportunity. Indeed, the COVID-19 pandemic and its restriction on movement and the massive confinement of the people ended up promoting a major TV consumption. And while reruns allowed TV programming to continue, the nostalgia produced by old telenovelas was also exploited as a niche industry. In this sense, TV channels from most of the countries in this report uploaded their files to online platforms, using diverse strategies. Some of them, for instance public channels TVN in Chile and RTP in Portugal, used the platform as a repository; while others, like Spain and Brazil, have 
developed VOD streaming platforms with various charging and financing strategies.

In virtually every country, audiovisual production was almost non-existent during the first three months of the pandemic. However, in mid-2020 filming was retaken by the advertise industry and by Amazon Prime and HBO international productions. This was the case of Uruguay, while in Colombia a process of production reconfiguration took place thanks to agreements among the above-mentioned producers, other production companies and some international distributors.

In Venezuela, the internationalization of national fiction took shape with series like Almas en Pena and Carolay, and, as other region experiences, small artistic and technical teams and scenes with few characters were the best options for reducing the risk of contagion and the quarantine of possible COVID-19 infected production groups. This change in the common mode of audiovisual creation was followed by Peru, specifically by Del Barrio Producciones that created a story just with five characters; and by Televisa that had to eliminate a love scene where two characters were kissing from one of its productions to avoid contagious, and created a color code according to the degree of contact and physical closeness among actors.

IN the US, Telemundo production, 100 dias para enamorarse, giving the impossibility of physical encounters among actors and considering the possibility of one of them to be quarantined, took a drastically solution consisting in green screens for filming scenes from home. Actors had to choreograph the scene at home with some mates, while some stuntmen were at the filming set backing the camera simulating the presence of the characters in the same place. But even though it was a creative solution, audiences complained in social medias about the telenovela characters lack of passion. Meanwhile, Spanish productions have to rewrite scrips to adapt them to the care needs imposed by the pandemic. Other action performed consisting in filming actors in 
different shots, a hundred meters apart, and then place them in parallel to simulate being in the same space.

Once health restrictions for audiovisual productions were lifted in the last quarter of 2020, it is interesting to note that the pandemic did not become a storyline for new productions, although it was used as an opportunity for both the topic addressed -closed to all kind of audiences- and the production strategy. Mexico highlights that just two productions, La Rosa de Guadalupe and Como Dice el Dicho, included the topic in some of their chapters. They approached the situation by placing the disease as the core of the story and creating a COVID-19 ambiance, characterized by the use of mask. Brazil presents a different case: Sob Pressão-Plantão COVID from Globo and some series that approach the challenges of love and intimacy in a forced cohabitation due to the pandemic.

To a lesser extent, Chile also presents two productions: one series, Historias de Cuarentena, and one telenovela with a twist of comedy that takes place in a residence building during the pandemic, Edificio Corona. The creative contributions trying to transform the restrictions of a reality changed by the COVID-19 were also observed in Spain with the release on VOD of En Casa and Relatos Con-fin-a-dos. The rest of Spanish series did not incorporate the coronavirus disease into their stories, excepting Cuéntame Cómo Pasó. This series began in 2001 telling the story of Alcántara family buying its first television in 1968, and uninterruptedly has been a reflection of what has happened in the country year after year. In an unprecedented way, in 2020 it makes a temporal jump from 1992 to present moment showing the main characters, already old, in a COVID-19 context.

In the following pages, teams from every Obitel country will present details that give shape to the state of TV fiction audiovisual production, distribution, exhibition and consumption. As it happened to all world economic activities, COVID-19 pandemic completely af- 
fected human life. Open television was already presenting a very complex crisis during the last years, and the coronavirus, in most of the cases, accelerated processes that were already under way, like streaming and the participation of international production platforms associated to VOD. Nevertheless, as it has been recalled by the Portuguese team, TV business is not weakened it just has changed, and its role as an encounter space for private and public is more present than ever, especially during the COVID-19 pandemic and the confinement we were forced to. 